\title{
Effects of Jackrabbit Grazing, Clipping, and Drought on Crested Wheatgrass Seedlings
}

\author{
BRUCE A. ROUNDY, GREG J. CLUFF, J. KENT MCADOO, AND RAYMOND A. EVANS
}

\section{Abstract}

The effects of black-tailed jackrabbits on crested wheatgrass (Agropyron desertorum) seedling establishment and utilization were monitored on a mesic and 2 xeric Wyoming big sagebrush (Artemisia tridentata spp. wyomingensis) sites in Nevada. Although jackrabbit densities (1.4 to 2.9/ha) and utilization were high, seedling survival was not significantly different $(p \leq 0.05)$ inside or outside rabbitproof exclosures even on the xeric sites during drierthan-normal springs. Seedling density was greater on the mesic than xeric sites, but good grass stands were produced on all sites. The smaller seeded areas (less than 60 ha) and the edge of the large seeded area $(400 \mathrm{ha})$ had the greatest forage utilization by rabbits. To determine the effects of defoliation and drought on seedling survival, seedlings in small tubes $(3.8 \mathrm{~cm}$ diameter and $20 \mathrm{~cm}$ deep) and in large tubes ( $10 \mathrm{~cm}$ diameter and $1 \mathrm{~m}$ deep) were watered and clipped at 7 different intervals. Seedlings grown in the smaller volume were more sensitive to clipping and drought than those grown in the larger soil volume. Seedlings watered less than weekly showed a trend toward higher survival when clipped every 3 or 4 weeks than when clipped more or less frequently. Clipping weekly and watering less than weekly greatly reduced root growth and seedling survival. Although infrequent grazing by rabbits could slightly increase seedling survival in a dry year, the additive effects of frequent grazing and drought could result in stand failure, especially on shallow or rocky soils with a small soil volume that limits water retention and root growth.

Rangelands of western North America are inhabited by several species of hares of the genus Lepus, commonly known as jackrabbits. The black-tailed jackrabbit (Lepus californicus) is probably the most abundant and widely distributed of the jackrabbits and therefore, most generally responsible for damage to crops and forage plants. Jackrabbit populations are very cyclic and virtually every western state has gone through severe crop depredation during population peaks (McAdoo and Young 1980). Large populations of jackrabbits have been considered a result and symptom of overgrazed rangelands (Fichter 1952) and a threat to crested wheatgrass seeded for range improvement (Goodwin 1960).

High consumption of range forage by jackrabbits has been well documented (Taylor et al. 1935, Currie and Goodwin 1966, Westoby and Wagner 1973). Although Westoby and Wagner (1973) suggested and Goodwin (1960) observed that jackrabbits affected crested wheatgrass seedling establishment, these effects have not been quantified. McGinnies (1973) showed that clipping crested wheatgrass seedlings to ground level once during the 5- month period following germination can reduce seedling survival by $50 \%$. However, for many years and clipping dates, clipping caused little or no seedling mortality, while for other years and clipping dates, high mortality was observed. Cook and Stoddart (1953) suggested that crested wheatgrass clipped early in the season would not produce regrowth under arid conditions. Mohammad et al. (1982) found $40 \%$ defoliation increased production of crested wheatgrass grown at $-0.5 \mathrm{MPa}$ water potential while $80 \%$ defoliation resulted

\footnotetext{
Authors are range scientist, formerly with USDA/ ARS, Reno, Nev., now at School of Renewable Natura] Resources, University of Arizona, Tucson 85721; range agronomist, formerly with University of Nevada, Reno, now at Department of Crop and Soil Science, University of New Mexico, Las Cruces; wildlife scientist, Renewable Resources Center, University of Nevada, Reno; and range scientist, USDA/ARS, Reno, Nev.

Manuscript accepted March 19, 1985.
}

in $100 \%$ mortality of plants at $-1.5 \mathrm{MPa}$ water potential. The purpose of this study was to determine the effects of black-tailed jackrabbits and clipping on crested wheatgrass seedling survival in relation to precipitation.

\section{Methods}

\section{Field Experiments}

Field experiments were conducted to determine jackrabbit utilization of seedlings and associated effects on seedling survival. Two locations, representing relatively high and low precipitation regimes for Wyoming big sagebrush communities in the Great Basin, were chosen for study. The relatively mesic site was an alluvial fan on the 71 Ranch in Lamoille Valley, northeast Nevada. The area is 1,950 $\mathrm{m}$ in elevation and receives $320 \mathrm{~mm}$ average annual precipitation. Approximately 400 ha were plowed and seeded at $9 \mathrm{~kg} / \mathrm{ha}$ with crested wheatgrass cultivar Nordan in the fall of 1981 . The relatively xeric area was on an alluvial fan at the University of Nevada's Gund Research and Demonstration Ranch in Grass Valley, central Nevada. The elevation is $1,870 \mathrm{~cm}$ and the annual precipitation averages $230 \mathrm{~mm}$. Shrubs on 2 sites at this location were eliminated by burning and $9 \mathrm{~kg} / \mathrm{ha}$ of crested wheatgrass cultivar Nordan were seeded on $60 \mathrm{ha}$ in the fall of 1981 and on 50 ha in the fall of 1982 (Table 1).

After seeding, rabbitproof exclosures $3 \times 3 \mathrm{~m}$ were placed on all sites. At the 71 Ranch, exclosures were placed along 4 transects from the edge to $400 \mathrm{~m}$ into the seeded area at $100-\mathrm{m}$ intervals. One exclosure was placed at each interval for each transect. On the 60-ha Gund Ranch site, 4 exclosures were placed at the edge and at $200 \mathrm{~m}$ from the edge in the center of the seeded area. On the 50-ha Gund site, exclosures were placed on 4 transects from the edge to $200 \mathrm{~m}$ into the seeded area at 50-m intervals. One exclosure was placed at each interval for each transect.

Seedling density and length of all culms and leaves of 10 randomly selected seedlings were determined on 1 permanently marked $1-\mathrm{m}^{2}$ plot inside and outside each exclosure. Data were collected in 2- to 4-week intervals from seedling emergence through September. Seedlings alive at the last sampling date in September were considered established. Seedling survival percentage was calculated from maximum and established seedling density for each permanently marked $1-\mathrm{m}^{2}$ plot. At the end of the growing season, one $1-\mathrm{m}^{2}$ plot was clipped along each of 7 transects at each $50-\mathrm{m}$ interval into each seeded area and one $1-\mathrm{m}^{2}$ plot inside each exclosure was clipped to determine forage yield.

Soil water potentials were measured with cylindrical gypsum blocks at 10 and $20 \mathrm{~cm}$ depths in each seeded area. Soil water potential was calculated from block resistance using standard calibration curves (Roundy et al. 1983). Predawn leaf water potentials were measured in psychrometer chambers (Brown and Collins 1980 ) for 10 grazed seedlings outside and 10 ungrazed seedlings inside each of 2 exclosures on the edge of the seeded area at the Gund Ranch on 3 dates in June and July in 1983. Herbaceous forage yield in the sagebrush outside each seeded area was sampled in $201-\mathrm{m}^{2}$ plots.

An index based on fecal pellet counts was used to estimate jackrabbit abundance in sagebrush habitat near the seeded area at the 71 Ranch in 1982, and similarly near the 50-ha seeded area at the Gund Ranch in 1983. Jackrabbit pellets were counted and 
Table 1. Site characteristics, seeding survival and jackrabbit utilization of three areas seeded to crested wheatgrass in Nevada.

\begin{tabular}{|c|c|c|c|}
\hline \multirow[b]{2}{*}{ Variable } & \multicolumn{3}{|c|}{ Location and Year of Evaluation } \\
\hline & $\begin{array}{c}71 \text { Ranch } \\
\text { (mesic) } \\
1982\end{array}$ & 1982 & $\begin{array}{c}\text { Gund Ranch } \\
\text { (xeric) } \\
1983\end{array}$ \\
\hline Seeded area & 400 & 60 & 50 \\
\hline Soil & $\begin{array}{l}\text { fine, montmorillonitic, mesic } \\
\text { Durixerollic Haplargid }\end{array}$ & \multicolumn{2}{|c|}{ loamy-skeletal, mixed mesic, xerollic Camborthid } \\
\hline Precipitation March through June (mm) & 240 & 98 & 96 \\
\hline $\begin{array}{l}\text { Soil water potential at } 10 \mathrm{~cm} \text { depth in early June } \\
\quad(\mathrm{MPa})\end{array}$ & $\geq-0.5$ & $\leq 1.5$ & -1.0 \\
\hline Herbaceous forage outside seeded area $(\mathrm{kg} / \mathrm{ha})$ & 333 & 57 & 12 \\
\hline \multicolumn{4}{|l|}{ Jackrabbits } \\
\hline $\begin{array}{l}\text { Density (no./ha) } \\
\text { Abundance index (pellets } / \mathrm{m}^{2} \text { ) }\end{array}$ & $\begin{array}{l}2.9 \mathrm{a}^{1} \\
14.9 \mathrm{a}\end{array}$ & $\begin{array}{l}2.4 \mathrm{ab} \\
-\end{array}$ & $\begin{array}{l}1.4 b \\
9.0 b\end{array}$ \\
\hline Distance to center of seeded area (m) & 400 & 220 & 200 \\
\hline \multicolumn{4}{|l|}{ Established seedlings/ $\mathrm{m}^{2}$} \\
\hline $\begin{array}{l}\text { Edge of seeded area } \\
\text { Ungrazed } \\
\text { Grazed }\end{array}$ & $\begin{array}{l}60.3 \mathrm{a} \\
37.8 \mathrm{~b}\end{array}$ & $\begin{array}{l}24.0 \mathrm{bc} \\
23.0 \mathrm{bc}\end{array}$ & $\begin{array}{l}11.5 \mathrm{c} \\
14.3 \mathrm{c}\end{array}$ \\
\hline $\begin{array}{l}\text { Center of seeded area } \\
\text { Ungrazed } \\
\text { Grazed }\end{array}$ & $\begin{array}{l}72.3 \mathrm{a} \\
61.8 \mathrm{a}\end{array}$ & $\begin{array}{l}13.3 \mathrm{c} \\
21.0 \mathrm{bc}\end{array}$ & $\begin{array}{l}15.5 \mathrm{c} \\
18.8 \mathrm{bc}\end{array}$ \\
\hline \multicolumn{4}{|l|}{ Seedling Survival (\%) } \\
\hline $\begin{array}{l}\text { Edge of seeded area } \\
\text { Ungrazed } \\
\text { Grazed }\end{array}$ & $\begin{array}{l}69 a-c \\
60 a-c\end{array}$ & $\begin{array}{l}71 \mathrm{a}-\mathrm{c} \\
54 \mathrm{bc}\end{array}$ & $\begin{array}{l}44 \mathrm{c} \\
55 \mathrm{bc}\end{array}$ \\
\hline $\begin{array}{l}\text { Center of seeded area } \\
\text { Ungrazed } \\
\text { Grazed }\end{array}$ & $\begin{array}{l}89 a \\
83 a\end{array}$ & $\begin{array}{l}90 a \\
69 a-c\end{array}$ & $\begin{array}{l}50 \mathrm{c} \\
62 \mathrm{a}-\mathrm{c}\end{array}$ \\
\hline $\begin{array}{l}\text { Forage yield in September of year area was seeded } \\
(\mathrm{kg} / \mathrm{ha})\end{array}$ & 186 & 146 & 636 \\
\hline \multicolumn{4}{|l|}{ Utilization ( $\%$ by weight) } \\
\hline $\begin{array}{l}\text { Edge of seeded area } \\
\text { Center of seeded area }\end{array}$ & $\begin{array}{l}88 \mathrm{a} \\
23 \mathrm{~b}\end{array}$ & $\begin{array}{l}96 a \\
94 a\end{array}$ & $\begin{array}{l}70 \mathrm{a} \\
70 \mathrm{a}\end{array}$ \\
\hline
\end{tabular}

'Means of the same variable in rows and columns not followed by the same letter are significantly different $(P<0.05)$, by Duncan's multiple range test.

removed monthly during August and September on $241-\mathrm{m}^{2}$ plots located randomly in each of the 2 areas. Jackrabbit densities (animals/ha) in the sagebrush-dominated vicinities of all 3 seeded areas were estimated in August using 4 1.2-km line transects in each area. Densities were calculated using a method similar to that described by Burnham and Anderson (1984) with area sampled determined by multiplying the length of the transect by the average perpendicular distance from the transect line to the jackrabbits that were observed.

\section{Clipping and Watering Experiments}

Two clipping and watering experiments were conducted to determine the effects of herbage removal and drought on seedling survival. In spring, 1982, crested wheatgrass seedlings were grown in plastic tubes $3.8 \mathrm{~cm}$ in diameter by $20 \mathrm{~cm}$ deep filled with silt-loam soil. Each tube had 1 seedling, and the tubes were planted at an experimental farm at Reno, Nev. Soil in the tubes was initially saturated, and the seedlings were subjected to 7 clipping and 7 watering treatments to simulate a spectrum of possible grazing and precipitation frequencies. The experiment was a completely randomized design with 10 seedlings for each clipping and watering treatment. Clipping treatments consisted of an unclipped control and clipping seedlings to ground level every $1,2,3,4,5$, and 6 weeks. Watering treatments consisted of adding $1 \mathrm{~cm}$ of water every $0.5,1,2,3,4,5$, and 6 weeks. The treatments lasted for 12 weeks, after which all plants were watered for 2 weeks and seedling survival and total root weights were determined.

A second experiment was conducted in spring, 1983, to determine the effects of clipping and watering on seedlings with a larger soil volume for root growth. Ten seedlings each were grown in plastic tubes $10 \mathrm{~cm}$ in diameter by $1 \mathrm{~m}$ deep. The tubes were filled with silt-loam soil and planted adjacent to where the small tube experiment had been planted the previous year. Initially, $6.4 \mathrm{~cm}$ of water were added to the air-dry soil in the tubes. This amount of water equals the minimum water precipitation (November through March) that could be expected $90 \%$ of the time in Elko, Nev. (U.S. Dept. Commerce, 1982), and brought the water content of the upper $30 \mathrm{~cm}$ of silt-loam soil to field capacity. All seedlings were given an additional $1 \mathrm{~cm}$ of water at the beginning of the experiment and then subjected to watering and clipping treatments at the same intervals as in the previous experiment. The experiment was a randomized complete block design with each of 3 blocks containing each clipping and watering treatment. Predawn leaf water potentials were measured in psychrometer chambers. Regrowth was measured weekly and all plants were watered and survival determined after 12 weeks. Seedlings in both experiments were shielded from natural precipitation by placing a fiberglass roof over the tubes when necessary.

Data from the field experiments and the clipping and watering experiments were analyzed for significance of main effects and 
interactions by analysis of variance ( $P \leq 0.05)$. Differences among means stated as significant were determined using Duncan's multiple range test $(P \leq 0.05)$.

\section{Results}

\section{Field Experiments}

Density of jackrabbits was similar at the 71 Ranch and Gund Ranch in 1982 (Table 1). However, jackrabbit density and abundance were significantly higher in the vicinity of the 71 Ranch seeded area in 1982 than in the vicinity of the seeded area at the Gund ranch in 1983. Despite the high jackrabbit population at the 71 Ranch in 1982, density of established seedlings was significantly higher at this mesic site than on the more xeric sites at the Gund Ranch. This was probably due to much higher spring precipitation and associated soil water potentials at the mesic than the xeric sites. The high production of herbaceous forage outside the seeded area at the mesic site (Table 1) could also have buffered the effect of jackrabbit grazing on established seedling density. Only on the edge of the mesic site did jackrabbits significantly decrease the number of established seedlings.

Seedling survival was statistically similar on all sites and was not significantly reduced by jackrabbit grazing (Table 1). Survival on all sites was greater than $40 \%$, and established seedling densities were greater than 13 seedlings $/ \mathrm{m}^{2}$. Average forage yield in September was similar for the mesic and xeric sites in 1982, but much higher for the xeric site at the Gund ranch in 1983. The high yield in 1983 was due to unusually high August precipitation and associated regrowth.

Forage utilization by rabbits was high and similar for all sites on the edge of the seeded areas (Table 1). Utilization in the center was similar to that on the edge of the smaller seeded areas at the Gund Ranch. Utilization on the large seeded area at the 71 Ranch significantly decreased at $400 \mathrm{~m}$ into the field (Fig. 1). Utilization by

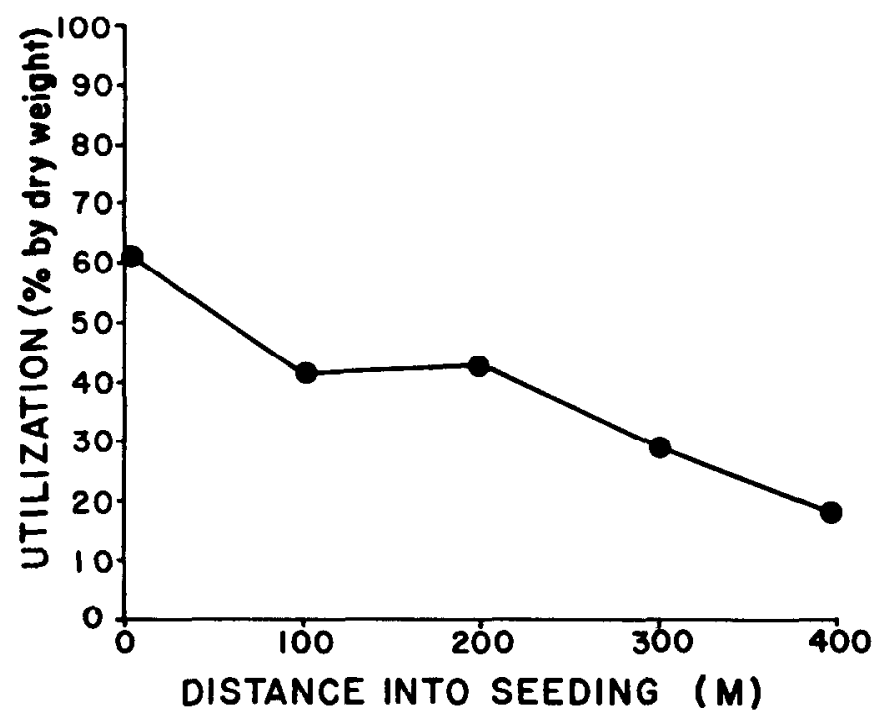

Fig. 1. Utilization of crested wheatgrass seedlings by jackrabbits at the 71 Ranch, Lamoille Valley, Nev.

jackrabbits during the growing season increased more rapidly on the small seeded areas than the larger seeded area (Fig. 2).

Predawn leaf water potentials were significantly higher (less negative) for grazed seedlings outside than ungrazed seedlings inside an exclosure on the first 2 of $\mathbf{3}$ dates when measurements were taken. Leaf water potentials for grazed and ungrazed seedlings, respectively, averaged -1.7 and $-2.3 \mathrm{MPa}$ on $30 \mathrm{June} ;-1.3$ and $-2.2 \mathrm{MPa}$ on $14 \mathrm{July}$; and -0.9 and $-1.4 \mathrm{MPa}$ on $27 \mathrm{July}$. The last measurement date was only 4 days after a rainstorm. Leaf water potentials of ungrazed seedlings in another exclosure, but with a lower seedling density than the exclosure reported above,

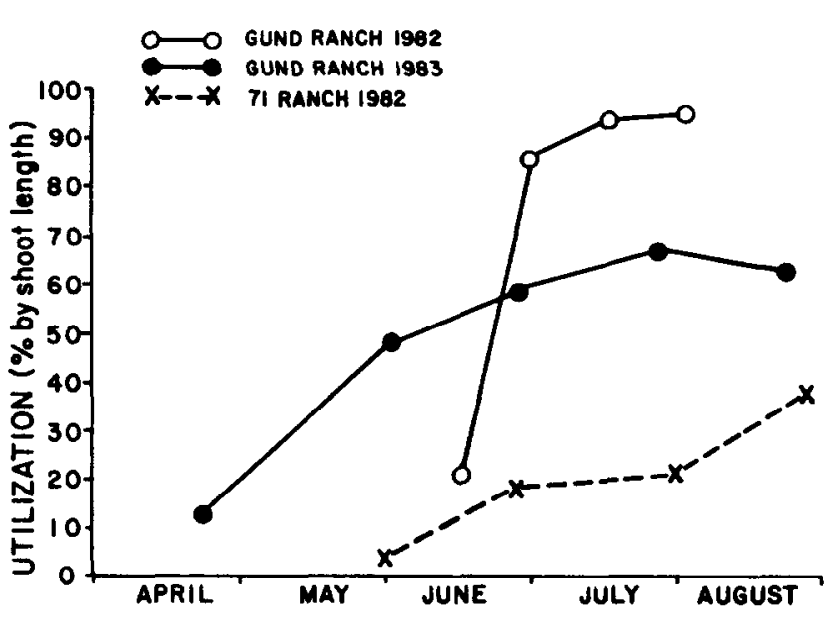

Fig. 2. Average utilization by jackrabbits of crested wheatgrass seedlings through the growing season for 2 small seeded areas (less than $60 \mathrm{ha}$ ) at the Gund Ranch in Grass Valley, Nev., and a large seeded area (400 ha) at the 71 Ranch in Lamoille Valley, Nev.

were not significantly different from those of grazed seedlings outside the exclosure for any of the 3 sample dates. Indications are that grazing by jackrabbits may, depending on precipitation and seed ling density, reduce plant water use and result in reduced water stress of grazed plants.

\section{Clipping and Watering Experiments}

Clipping and lack of water significantly reduced seedling survival in both the small and large-tube experiments. Clipping every week resulted in no seedling survival in the small tubes, even when watered weekly (Fig. 3a). In the larger tubes, weekly clipping significantly reduced survival, but some seedlings clipped weekly still survived at most watering intervals (Fig. 3b). Seedlings watered at least weekly had significantly higher survival in both the small and large tubes than seedlings watered less frequently.

In the small tubes, clipping significantly reduced root yield at the shorter watering intervals (Fig. 4). Root yield was so reduced when seedlings were watered less than once a week that clipping had little additional effect on root yield. The experimental design for the small tubes did not permit a statistical test for significance of the interaction between clipping and water frequency. However, the data show a trend toward increased survival of seedlings watered every 2 weeks or less when clipped every 4 weeks than when clipped more or less frequently (Fig. 3a).

In the large tubes, the interaction between clipping and watering treatments was not statistically significant. However, there was a trend for seedlings watered less than once a week to have greater survival when clipped every 3 weeks than when clipped more or less frequently (Fig. 3b).

In the large tubes, predawn leaf water potential of seedlings watered weekly decreased significantly with increasing time between clipping (Fig. 5). Water potential of unclipped plants also significantly decreased with increasing time between watering. Regrowth of seedlings in the large tubes was significantly less for plants clipped weekly than for those clipped less frequently (Fig. 6). Plants watered twice per week had significantly higher regrowth than those watered weekly, which, in turn, had significantly higher regrowth than plants watered every 2 weeks or less. Regrowth occurred no matter when seedlings were first clipped between 13 June and 18 July, but seedlings clipped for the first time in July had no regrowth when watered less than weekly.

\section{Discussion}

We hypothesized that jackrabbit grazing would destroy crested 


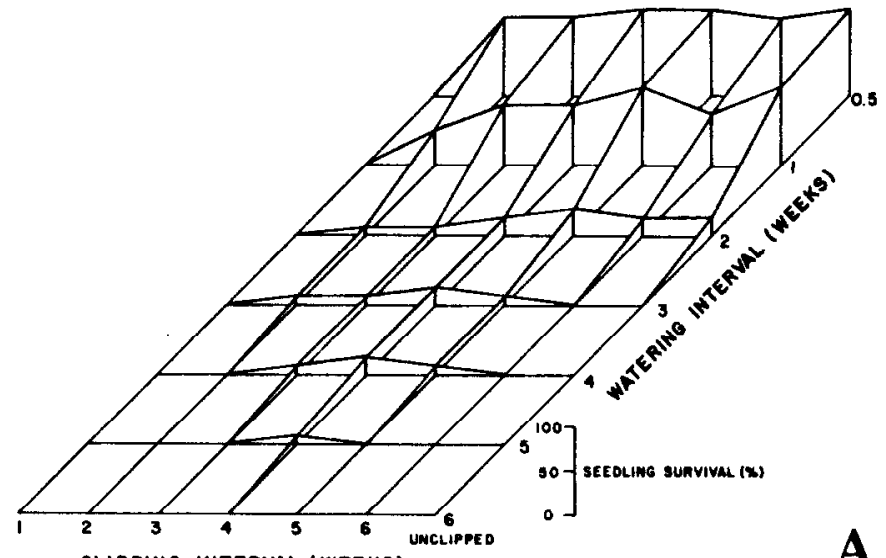

CLIPPING INTERVAL (WEEKS)

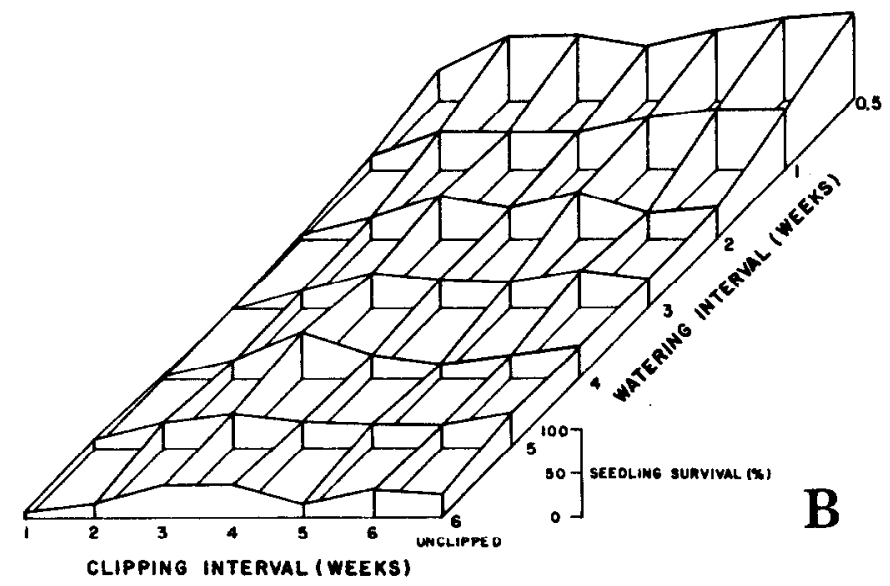

Fig. 3. Crested wheatgrass seedling survival as a function of clipping and watering intervals for seedlings grown in small tubes (a) and large tubes (b).

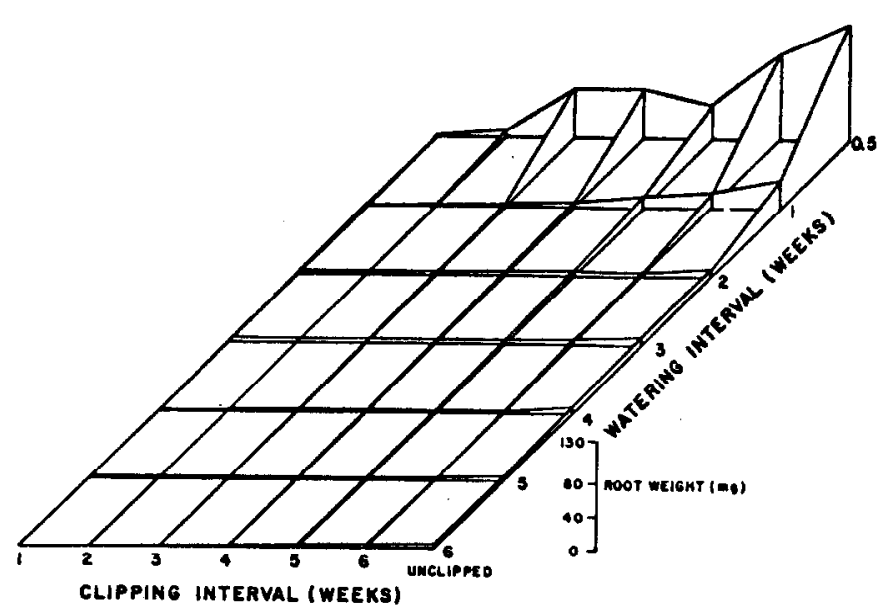

Fig. 4. Root weight of crested wheatgrass seedlings grown in small tubes in relation to clipping and watering interval.

wheatgrass seedings under droughty conditions. High densities of jackrabbits and associated high forage utilization did not reduce seedling survival on a mesic site or a xeric site with below-average spring precipitation. Average March through June precipitation at the Gund ranch (xeric) site is $\mathbf{4 0} \mathrm{mm}$ more than that received in 1982 and 1983, when the jackrabbit studies were conducted. Min-

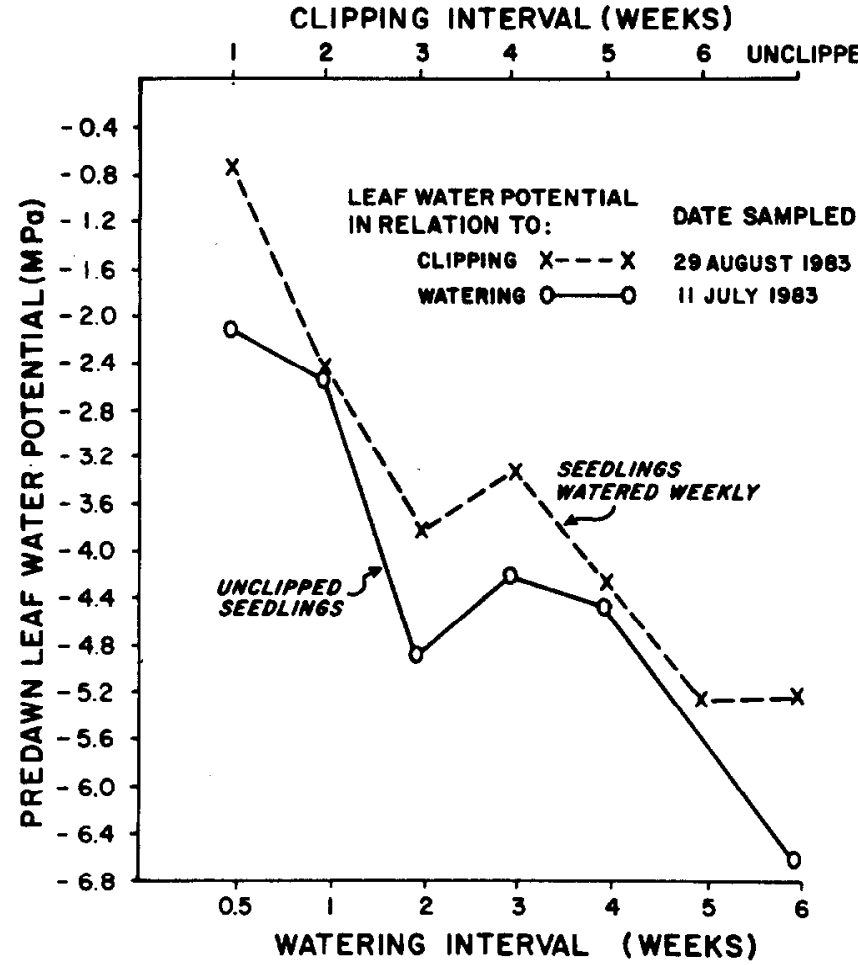

Fig. 5. Predawn leaf water potentials of crested wheatgrass seedlings watered weekly in relation to clipping interval and of unclipped seedlings in relation to watering interval.

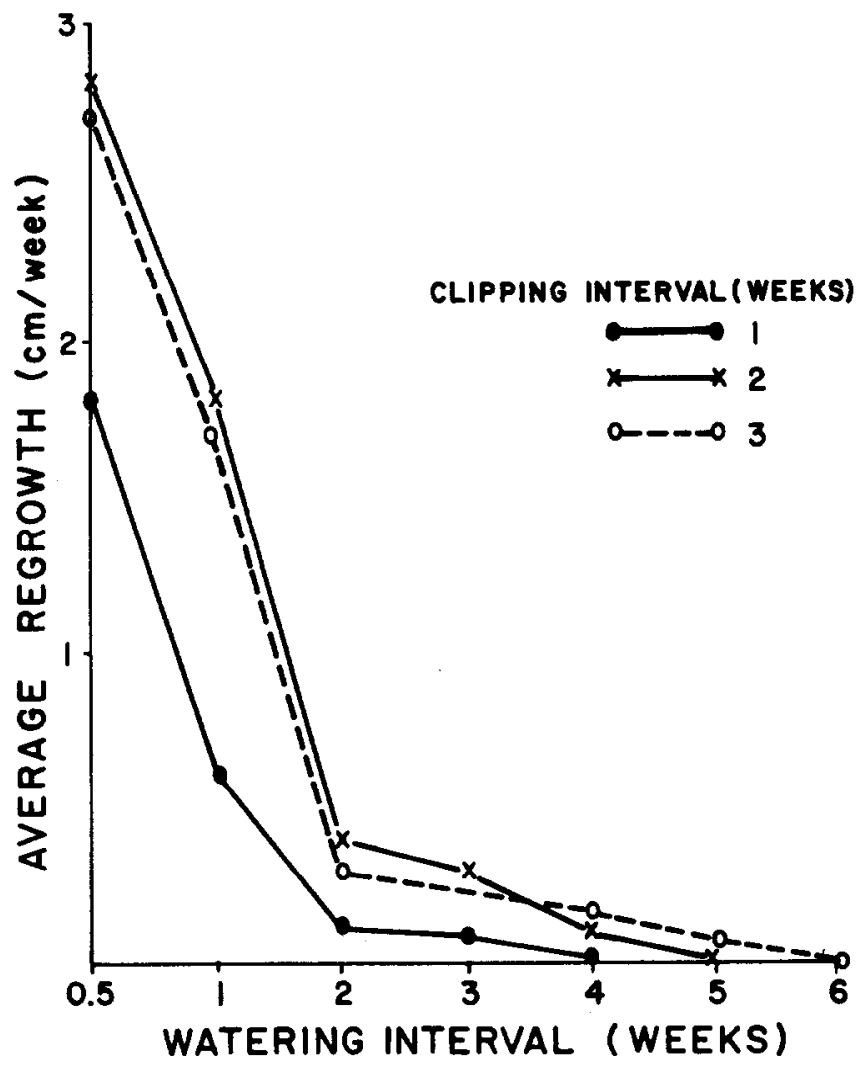

Fig. 6. Average weekly regrowth of crested wheatgrass seedlings in relation to clipping and water interval.

imum established seedling densities were higher than the 10 seedlings $/ \mathrm{m}^{2}$ considered to be good establishment for sites receiving 250 to $300 \mathrm{~mm}$ annual precipitation (Hyder and Sneva 1954). 
Jackrabbit populations reached a cyclic high during 1982 in northern and central Nevada (Unpublished data, USDA, ARS and Univ. of Nevada, Reno). Densities were near the maximum reported in the literature reviewed by Stoddart (1972) and were higher than the population peak documented by Gross et al. (1974). Although jackrabbits did not reduce the establishment of crested wheatgrass, they consumed high amounts of forage, especially on the smaller seeded areas. Forage utilization on the larger seeded area was concentrated in a band less than $300 \mathrm{~m}$ into the seeding, as has also been reported by Westoby and Wagner (1973). Small and irregular-shaped seeded areas with extensive edges would be expected to receive greater utilization by high populations of jackrabbits than would large seeded areas with less edge.

As suggested by Cook and Stoddart (1953), regrowth of crested wheatgrass is restricted by lack of water. The clipping and watering experiments suggest that tolerance to defoliation as affected by drought is dependent on the soil volume available for root growth and water storage. Differences in seedling response between the small- and large-tube experiments were not due to temperature differences. Maximum, minimum, and average temperatures in June through August were very similar in 1982 and 1983 at Reno, when the small- and large-tube experiments were conducted, respectively. Seedlings with a small volume for root growth are very sensitive to weekly defoliation even when watered frequently. Crested wheatgrass seedlings on shallow, rocky soils with low soil volume for water retention and root growth may be more vulnerable to jackrabbit grazing than those on deeper soils with high water holding capacity and greater volume for root growth.

The clipping and water experiments also indicate the great drought tolerance of crested wheatgrass seedlings and suggest the possible effects of spring precipitation on seedling survival during years when lack of winter precipitation results in limited soil water recharge. Unclipped plants receiving $1 \mathrm{~cm}$ of water every 2 weeks or less than every 2 weeks averaged $35 \%$ survival compared to $70 \%$ and $100 \%$ survival of plants receiving $1 \mathrm{~cm}$ of water once and twice a week, respectively. Seedlings watered less than once a week showed a trend toward increased survival when clipped at intervals of 3 to 4 weeks than when clipped more or less frequently. This was probably due to conservation of soil water. Infrequent grazing could increase seedling survival on a dry year by reducing transpiration and conserving soil water, thereby allowing a longer period of growth than if plants were ungrazed. Frequent clipping resulted in greatly decreased root growth, so the additive effects of frequent grazing and drought could greatly reduce seedling survival if roots are unable to extend below the surface soil drying front. Figure 3 illustrates the additive negative effects of clipping and drought on seedling survival even when the volume available for root growth is large. In the large tubes, seedlings left unclipped, but watered every 4 weeks had $37 \%$ survival; seedlings watered twice a week and clipped once a week had $33 \%$ survival; but seedlings clipped once a week and watered every 4 weeks had only $3 \%$ survival.

The clipping and watering experiments suggest that crested wheatgrass seedlings were successfully established in the field experiments in this study due to adequate soil water for growth and probably less than weekly defoliation even with high utilization by jackrabbits. High populations of jackrabbits would probably not decrease establishment of crested wheatgrass seedlings in most years, but could destroy seedlings on a small seeded area in a very dry year, especially on a shallow soil where root growth and water holding capacity are limited.

\section{Literature Cited}

Brown, R.W., and J.M. Collins. 1980. A screen-caged thermocouple psychrometer and calibration chamber for measurements of plant and soil water potential. Agron. J. 72:851-854.

Burnham, K.P., and D.R. Anderson. 1984. The need for distance data in transect counts. J. Wildl. Manage. 48:1248-1254.

Cook, C.W., and L.A.Stoddart. 1953. Some regrowth responses of crested wheatgrass following herbage removal. J. Range Manage. 6:267-270.

Currie, P.0., and D.L. Goodwin. 1966. Consumption of forage by blacktailed jackrabbits on salt-desert range of Utah. J. Wildl. Manage. 30:304-311.

Fichter, E. 1952. Control of jackrabbits and prairie dogs on rangelands. J. Range Manage. 6:16-24.

Goodwin, D.L. 1960. Seven jackrabbits equal one ewe. Utah Farm and Home Sci. 21:38-39.

Gross, J.E., L.C. Stoddart, and F.H. Wagner. 1974. Demographic analysis of a northern Utah jackrabbit population. Wildlife Monogr. 40.

Hyder, D.N., and F.A. Sneva. 1954. A method for rating the success of range seeding. J. Range Manage. 7:89-90.

McAdoo, J.K., and J.A. Young. 1980. Jackrabbits. Rangelands 2:135-138.

McGinnies, W.J. 1973. Effect of clipping on survival of crested wheatgrass seedlings. J. Range Manage. 26:452-453.

Mohammad, N., D.D. Dwyer, and F.E. Busby. 1982. Responses of crested wheatgrass and Russian wildrye to water stress and defoliation. J. Range Manage. 35:227-230.

Roundy, B.A., J.A. Young, C.J. Cluff, and R.A. Evans. 1983. Measurement of soil water on rangelands. USDA Agr. Res. Ser. Agr. Res. Results. ARR-W-31.

Stoddart, L.C. 1972. Population biology of the black-tailed jackrabbit (Lepus californicus) in northern Utah. Ph.D. Diss. Utah State Univ., Logan.

Taylor, W.P., C.T. Vorhies, and P.B. Lister. 1935. The relation of jackrabbits to grazing in southern Arizona. J. Forestry 33:490-498.

U.S. Dep. Commerce, National Oceanic and Atmospheric Admin. 1982. Monthly normals of temperature, precipitation, and heating and cooling degree days 1951-80, Nevada. National Climatic Center, Ashville, NC.

Westoby, M., and F.H. Wagner. 1973. Use of crested wheatgrass seeding by black-tailed jackrabbits. J. Range Manage. 26:349-352.
MOVING? Please try to give us four weeks notice. Send your present address label and this form to Society for Range Management

2760 W. 5 th Ave.

Denver, Colo. 80204

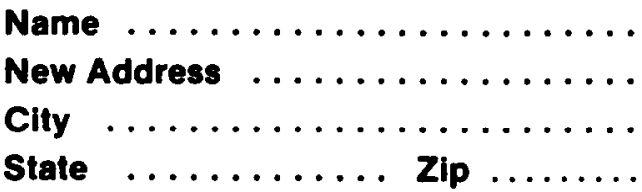

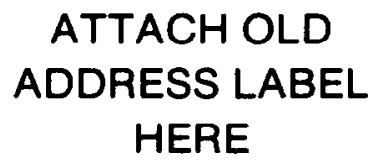

